\title{
Ultrastructural evaluation of compression wood-like properties of common juniper (Juniperus communis L.)
}

\section{Hänninen, Tuomas}

2012

Hänninen , T , Tukiainen , P , Svedström , K , Serimaa , R , Saranpää , P , Kontturi , E , Hughes, M \& Vuorinen, T 2012 , ' Ultrastructural evaluation of compression wood-like properties of common juniper (Juniperus communis L.) ' , Holzforschung : international journal of the biology, chemistry, physics and technology of wood, vol. 66 , no. 3 , pp. 389-395 . https://doi.org/10.1515/HF.2011.166

http://hdl.handle.net/10138/39137

https://doi.org/10.1515/HF.2011.166

publishedVersion

Downloaded from Helda, University of Helsinki institutional repository.

This is an electronic reprint of the original article.

This reprint may differ from the original in pagination and typographic detail.

Please cite the original version. 


\section{Ultrastructural evaluation of compression wood-like properties of common juniper (Juniperus communis L.)}

\author{
Tuomas Hänninen ${ }^{1, *}$, Pekka Tukiainen ${ }^{1}$, \\ Kirsi Svedström² ${ }^{2}$, Ritva Serimaa ${ }^{2}$, Pekka Saranpää ${ }^{3}$, \\ Eero Kontturi ${ }^{1}$, Mark Hughes ${ }^{1}$ and Tapani Vuorinen ${ }^{1}$ \\ ${ }^{1}$ Department of Forest Products Technology, School of \\ Chemical Technology, Aalto University, Aalto, Finland \\ ${ }^{2}$ Department of Physics, Division of Materials Physics, \\ University of Helsinki, Helsinki, Finland \\ ${ }^{3}$ Finnish Forest Research Institute Metla, Vantaa, Finland \\ * Corresponding author. \\ Department of Forest Products Technology, \\ School of Chemical Technology, \\ Aalto University, P.O. Box 16300, \\ FI-00076 Aalto, Finland \\ Phone: +358-50-512-4223 \\ E-mail: tuomas.hanninen@ aalto.fi
}

\begin{abstract}
To date, very little is known about the ultrastructure of common juniper, Juniperus communis L (juniper). In this study, the mechanical properties of juniper, its chemistry and ultrastructure has been analyzed. The data are presented in comparison to the normal wood (NW) and compression wood (CW) of spruce. Helical grooves, which are a characteristic of $\mathrm{CW}$, were clearly visible in micrographs of juniper. The angle of the grooves with respect to the fiber axis was ca. $40^{\circ}$, which correlates with the microfibril angle determined by $\mathrm{X}$-ray diffraction. Data from 4-point bending tests show that juniper and spruce $\mathrm{CW}$ exhibited similar behavior. The elastic moduli of both species were only ca. half from that of NW spruce. The composition of juniper fibers resembled that of $\mathrm{CW}$ fiber with respect to high lignin and hemicelluloses contents. However, the galactose content in $\mathrm{CW}$ of juniper was low and in CW of spruce was high. Raman imaging clearly revealed that the lignin/cellulose ratio in the fiber cell wall of juniper was similar to that of NW spruce.
\end{abstract}

Keywords: Juniperus communis L.; mechanical properties; microfibril angle (MFA); Raman imaging.

\section{Introduction}

Trees respond to stimuli - such as inclination of the ground, strong wind, or heavy snow on the branches - by forming reaction wood. Hardwoods develop the so-called tension wood in an attempt to pull the stem (or branches) upright, whereas softwood forms compression wood (CW) to generate compressive stress. CW differs from normal wood (NW) in its chemistry, mechanical properties, and the structure of the fibers (Timell 1986). The formation, physical and chemical characteristics of reaction wood are still a matter of scientific interest as demonstrated in the literature of the past decade. For example, the following topics have been the focus of attention: mechanical properties (Gindl 2002; Gindl and Teischinger 2003), air permeability (Tarmian and Perré 2009), wood-water relationship (Perré 2007), viscoelastic properties (Placet et al. 2007), morphological and chemical properties (Önnerud 2003; Yeh et al. 2005, 2006; Altaner et al. 2007; Tokareva et al. 2007; Kibblewhite et al. 2010), and quantitative chemical indicators to assess the gradation of CW (Nanayakkara et al. 2009). One of the distinct features of $\mathrm{CW}$ is the presence of the $\mathrm{S} 2_{\mathrm{L}}$ layer, which is within the $\mathrm{S} 2$ cell wall containing a high concentration of lignin (Timell 1986; Donaldson et al. 1999; Gierlinger et al. 2010). CW cells are also known to lack the S3 layer and have helical grooves in the S2 layer (Timell 1982).

The wood of the genus Juniperus has many CW-like features. Common juniper (Juniperus communis L.), referred to in this work as juniper, is widely distributed in the northern hemisphere. It is known for its berries, which gives the flavor to gin, strong scented extractives, and resilient mechanical properties (Eckenwalder 2009). The papermaking properties of pulped juniper were reported by Hänninen et al. (2011a) and the fiber dimensions of juniper resemble those of $\mathrm{CW}$ from other softwood species. Indeed, the juniper fibers were shorter and their cell wall was thicker, which is commonplace with $\mathrm{CW}$ fibers. Compared with the NW of other softwoods, a high microfibril angle (MFA), which is a common feature of CW, is an attribute for juniper (Kantola and Seitsonen 1961; Kantola and Kähkönen 1963). In addition, rounded tracheids and intercellular spaces are typical for the NW of the genus Juniperus, which are commonly characteristics of CW (Timell 1983). The mechanical properties of juniper bear a closer resemblance to those of CW than to NW spruce. It is intriguing that the NW in one species should possess characteristics that are so close to CW.

The aim of the present study was to investigate morphological and chemical peculiarities of juniper in comparison to spruce CW and NW. The ultrastructural details were analyzed by light microscopy, Raman imaging, and X-ray diffraction. In addition, the chemical composition and mechanical properties were determined.

\section{Materials and methods}

Norway spruce (Picea abies [L.] Karst.) was obtained from Mikkeli, south-eastern Finland. Samples were cut from the same stem; NW being taken from approximately breast height and CW lower in the stem, close to the stump. Stems of common juniper (Juniperus 
communis L.) were collected from Solböle, south-western Finland. Samples were cut from the same, approximately $7 \mathrm{~cm}$ thick, straight and branchless stem roughly at a height of $50 \mathrm{~cm}$. This material does not contain juvenile wood (JW).

Radial sections $16 \mu \mathrm{m}$ in thickness were cut with a cryomicrotome at $-14^{\circ} \mathrm{C}$. Sections were stained with safranin-Alcian blue and the helical grooves or cavities were observed under a Olympus BX60 microscope connected to Spot insight B/W video camera (Diagnostic Instruments, Inc., USA) and Image-Pro plus for Windows program. Images of radial sections were captured at $20 \times$ magnification.

\section{Static bending tests}

Juniper, spruce NW and CW were cut to small rectangular beams with dimensions $3 \mathrm{~mm}(\mathrm{r}), 6 \mathrm{~mm}(\mathrm{t})$, and $60 \mathrm{~mm}$ (1). The specimens were conditioned to constant weight in a climate chamber (RH 65\% and $\mathrm{T} 20^{\circ} \mathrm{C}$ ) for ca. 2 weeks prior to testing. The annual ring widths in juniper were smaller than those in spruce NW and CW, which resulted in a different number of annual rings in the specimens. This gave rise to differences in the amounts of late wood (LW) different samples, which may have affected the stiffness of the specimens.

The mechanical properties were determined by a four-point bending test with an outer span of $37.5 \mathrm{~mm}$ and an inner span of 12.5 $\mathrm{mm}$ (Figure 1). Testing was conducted on a small loading device (stepper motor driven) designed for the use with a light microscope (Wild MZ8, Leica, Wetzlar, Germany). Force was measured with a $500 \mathrm{~N}$ load cell (U9B, HBM, Darmstadt, Germany). Loading was conducted under displacement control at a cross-head displacement rate of $0.5 \mathrm{~mm} \mathrm{~min}^{-1}$. Specimens were loaded to $50 \mathrm{~N}$ and then unloaded to $5 \mathrm{~N}$ prior to the actual measurement, where samples were loaded to failure. During testing, load and cross-head displacement data were recorded (Solartron AX/2.5/SH, Solartron metrology, West Sussex, UK) and the specimen observed with an optical microscope equipped with a CCD camera (C-Mount 3-CCD, JVC, Japan). Micrographs were captured at $5 \mathrm{~N}$ intervals.

The longitudinal modulus of elasticity (MOE) was calculated from classical beam theory for homogeneous beams of rectangular cross-section. Total cross-sectional area was used. MOE was calculated from the crosshead displacement (assumed to be equal to the deflection of the beam under the loading head) and load data between 0.1 and 0.4 of the maximum load. The effect of shear forces and indentation of the supports and loading head were neglected.

$M O E_{B}=\frac{5}{27} \cdot \frac{L^{a}}{T \cdot R^{a}} \cdot \frac{\Delta F}{\Delta f}$

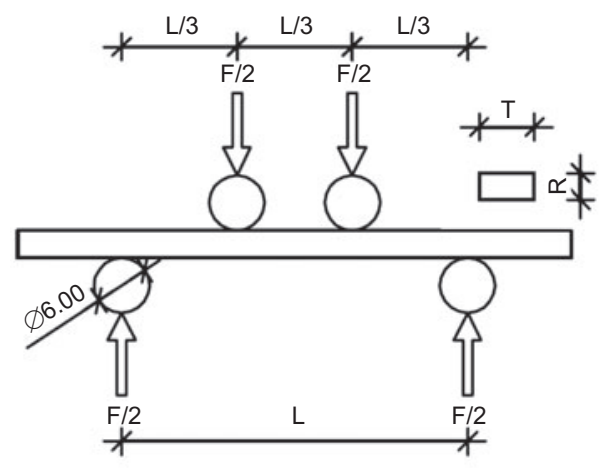

Figure 1 The 4-point bend test set-up; $L$ is outer span, $L / 3$ is inner span, $R$ is specimen height, and $T$ is specimen width. where $M O E_{B}$ is modulus of elasticity determined in 4-point bending, $L$ is the outer span, $T$ is the specimen width, $R$ is the specimen height, $\Delta F$ is the load difference, and $\Delta f$ is the deflection under the loading head (Gere 1997).

\section{Chemical composition}

Wood samples were milled in a Wiley mill and extracted with acetone (AnalaR NORMAPUR, VWR, Fontenay-sous-Bois, France) to determine the extractives content. The Klason lignin and carbohydrate contents were determined based on acid hydrolysis according to a method detailed by Sluiter et al. (2008). The monosaccharides in the resulting hydrolysates were quantified by high-performance anionexchange chromatography (HPAEC) (Dionex ICS-3000, CarboPac PA20 column, pulsed amperometric detection, PAD).

\section{X-ray diffraction (XRD)}

For XRD, all samples were cut tangentially from the stems with a scalpel to a (radial) thickness of ca. $1 \mathrm{~mm}$, dimensions: 10 (l) $\times 10$ (t) $\mathrm{mm}^{2}$. Two samples were cut from the juniper stem in the middle between the pith and bark ( $1 \mathrm{~mm}$ thick); the pieces included several annual rings. The spruce NW samples were cut from the earlywood (EW) of the 16th and the 19th annual rings, and the CW samples were cut from the EW of the 20th, the 21st, and the 22nd annual rings.

The MFA distributions were determined from the azimuthal intensity profiles of the cellulose reflections 200 and 004 measured in symmetrical transmission mode by means of the set-up with the 4-circle goniometer as described by Hänninen et al. (2011a). The MFAs were determined from the intensity profiles by fitting pairs of Gaussian functions into the profiles as detailed by Sarén et al. (2001).

Diffraction patterns were measured with the same X-ray set-up for determining the dimensions of cellulose crystallites. The crystal length was determined from the reflection 004 measured in symmetrical transmission mode, and the crystal width was determined from the reflection 200 measured in symmetrical reflection mode. The crystal dimensions were obtained from the widths and positions of the reflections by the Scherrer equation (Andersson et al. 2003). The azimuthal intensity profiles of the four juniper samples (Hänninen et al. 2011a) were also analyzed here at high angles (close to $90^{\circ}$ ).

\section{Raman imaging}

Sample preparation and Raman imaging were performed according to Hänninen et al. (2011b). The samples were analyzed with an $\alpha 300 \mathrm{R}$ Confocal Raman microscope (Witec GmbH, Germany, www.witec.de) at ambient conditions. The instrument works with frequency doubled Nd: YAG laser $(532.35 \mathrm{~nm}, 10 \mathrm{~mW})$ and a Nikon $100 \times(\mathrm{NA}=0.95)$ air objective, and it was equipped with a DU970NBV EMCCD camera behind a 600 -line $\mathrm{mm}^{-1}$ grating. The excitation laser was polarized horizontally. The integration times and measured areas differed from image to image depending on how prone the samples were to burning during measurement. Only the LW cells could be analyzed as the resolution of Raman imaging is ca. $300 \mathrm{~nm}$ due to the diffraction limit and thus the features of thin walled EW cells would certainly be indistinguishable.

\section{Results and discussion}

Micrographs of Norway spruce $\mathrm{CW}$ and juniper are presented in Figure 2. Helical grooves or cavities characteristic to $\mathrm{CW}$ (Timell 1986) were clearly visible on juniper micrographs 

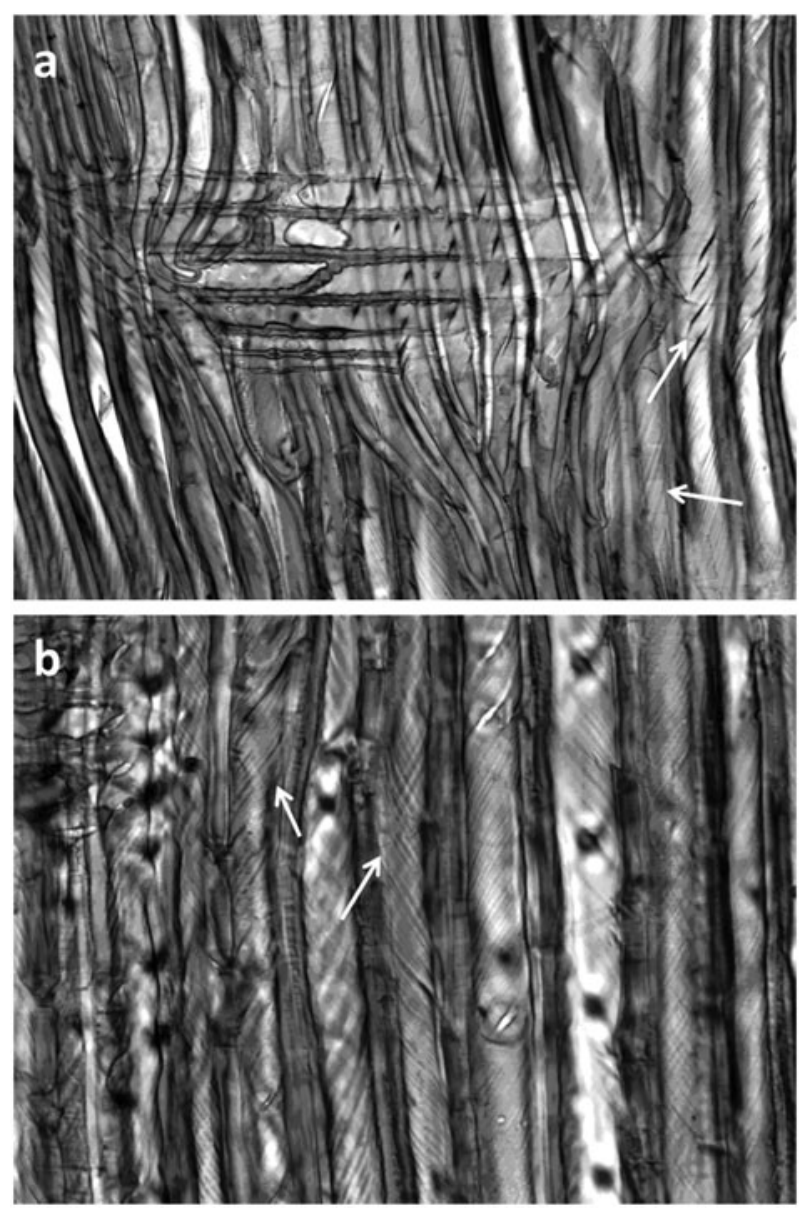

Figure 2 Radial sections of (a) compression wood of spruce and (b) common juniper. Helical grooves or cavities indicating high MFA of the cell wall are clearly visible. Some of the defects are indicated with arrows.

(Figure 2b). The angle of the grooves with respect to the fiber axis is ca. $40-45^{\circ}$. This correlates well with the MFA data from XRD (Table 1).

The mean MFA measured by XRD of both spruce CW and juniper was around $35^{\circ}$ (Table 1), which corresponds to literature values. However, a very large variation in MFA $\left(24.7-37^{\circ}\right.$ ) was reported for juniper (Kantola and Seitsonen 1961; Kantola and Kähkönen 1963; Timell 1986; Burgert et al. 2004). Reportedly, MFA values for the juniper CW are very close to the MFA values in the juniper NW (Kantola and Seitsonen 1961), and this is the reason why the presence of CW cannot be entirely excluded.

The mean and standard deviation of the MFA given in Table 1 correspond to the largest peak observed in the azimuthal intensity profiles of the samples (Figure 3 ). It was assumed that this peak arises from the S2 layer of the cell wall, because it is the thickest. From the azimuthal intensity profiles of juniper and spruce CW contribution, other than from the S2 cell wall, could be distinguished (peak 1 in Figure 3). The contribution was assumed to be from the S1 layer, as CW lacks the S3 layer and the arrangement of the fibrils in the S1 is thought to be random. The mean MFAs in the S1 layer were $84-89^{\circ}$
Table 1 The mean microfibril angle (MFA) of the S2 cell wall layer, the crystal length and width determined by XRD.

\begin{tabular}{lccc}
\hline \multicolumn{1}{c}{ Sample } & MFA $\left(^{\circ}\right)$ & Crystal length (nm) & Crystal width (nm) \\
\hline Spruce & $0.2(7)$ & $40 \pm 5$ & $3.08 \pm 0.05$ \\
Spruce CW & $35(8)$ & $20 \pm 2$ & $3.06 \pm 0.05$ \\
Juniper & $35(9)$ & $21 \pm 2$ & $2.92 \pm 0.05$ \\
\hline
\end{tabular}

The standard deviation of the MFA values is presented within parentheses. The error margins for the dimensions of the crystallites are based on the accuracy of the measurement and analysis.

and $66-90^{\circ}$ for spruce $\mathrm{CW}$ and juniper, respectively, which are in agreement with literature data, where an almost perpendicular orientation to the fiber axis was found (Brändström 2001). The ratio of the integrated intensities of peak $1\left(I_{1}\right)$ to that of peaks 1 and $2\left(I_{1}+I_{2}\right)$ was $17 \%-20 \%$ for spruce $\mathrm{CW}$ and $11 \%-41 \%$ for juniper. If the peaks 1 and 2 correspond to the $\mathrm{S} 1$ and the $\mathrm{S} 2$ as assumed, then this ratio corresponds to the thickness ratio of the layers.

The crystal length is the same in juniper and spruce $\mathrm{CW}$ (ca. $20 \mathrm{~nm}$ ), whereas in spruce NW it was twice as high (ca. $40 \mathrm{~nm}$ ). A shorter crystal length in CW was found by Tanaka et al. (2005). Shorter crystal lengths result in higher elasticity of the MF because the number of dissipative amorphous areas is increased (Page 1983). Crystals in juniper wood (Table 1) were longer and thinner than in juniper pulp (Hänninen et al. 2011a). Similar changes in the crystal dimensions during pulping of spruce and birch wood were discussed in detail by Leppänen et al. (2010). NW and CW of spruce had the same crystal width, whereas it was slightly smaller in juniper. The crystal widths determined from the cellulose reflection 200 are presented in Figure 4. All crystal widths are in agreement with literature values (Andersson et al. 2003; Davidson et al. 2004; Yanagisawa et al. 2005; McLean et al. 2010).

MFA and density belong to the most important factors affecting the mechanical properties of wood. An increase in density elevates the stiffness of the material due to the greater

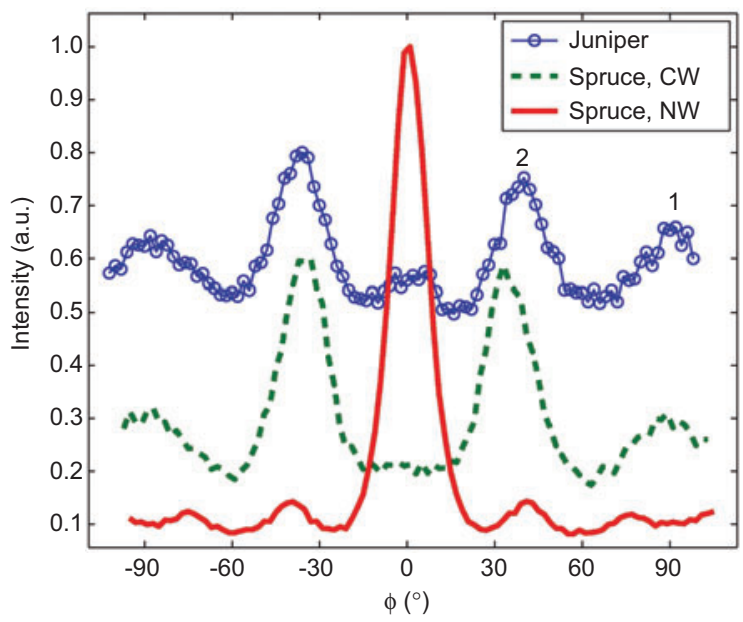

Figure 3 Azimuthal intensity profiles of the cellulose reflection 004 for juniper, spruce compression wood $(\mathrm{CW})$, and spruce normal wood (NW). 


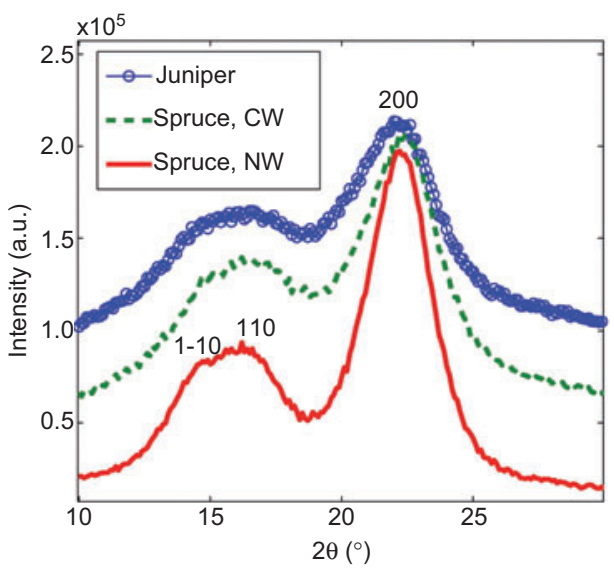

Figure 4 Radial intensity profile of the cellulose reflection 200 for juniper, spruce compression wood (CW), and spruce normal wood $(\mathrm{NW})$, from which the cellulose crystal widths were determined.

volume of cell wall material. By contrast, increasing MFA leads to decreasing stiffness (Evans and Ilic 2001; Salmén and Fahlén 2009; McLean et al. 2010). The elastic moduli of the samples with high MFA (Table 2) - in juniper and spruce $\mathrm{CW}$ - were clearly lower than that of NW spruce. Although $\mathrm{CW}$ and juniper were significantly denser than spruce NW, the effect of MFA is clearly reflected in the data of elastic modulus. The specific stiffness data of NW spruce (MOE/p or $M O E / \rho^{2}$, where $\rho$ is density) are more than twice as high than those of spruce $\mathrm{CW}$ or juniper. Similar differences between spruce and yew, the MFA and density data of which are also very high, were already observed by Keunecke et al. (2008).

Table 2 Elastic moduli (MOE), densities, and maximum stresses at break values for spruce, spruce compression wood $(\mathrm{CW})$, and juniper samples.

\begin{tabular}{lccc}
\hline Sample & $\begin{array}{c}\text { Density } \\
\left(\mathrm{kg} \mathrm{m}^{-3}\right)\end{array}$ & $\begin{array}{c}\text { MOE } \\
(\mathrm{MPa})\end{array}$ & $\begin{array}{c}\text { Bending strength } \\
(\mathrm{MPa})\end{array}$ \\
\hline Spruce & 415 & 8215 & 72 \\
& 455 & 7944 & 68 \\
& 529 & 7693 & 76 \\
& 440 & 9583 & 82 \\
Spruce CW & 428 & 9591 & 75 \\
& $\mathbf{4 5 4} \pm \mathbf{4 5}$ & $\mathbf{8 6 0 5} \pm \mathbf{9 1 5}$ & $\mathbf{7 4} \pm \mathbf{5}$ \\
& 600 & 5116 & 92 \\
& 572 & 4789 & 95 \\
& 564 & 4514 & 90 \\
Juniper & 563 & 4743 & 93 \\
& 574 & 5646 & 97 \\
& $\mathbf{5 7 5} \pm \mathbf{1 5}$ & $\mathbf{4 9 6 2} \pm \mathbf{4 3 9}$ & $\mathbf{9 3} \pm \mathbf{3}$ \\
& 809 & 4709 & 113 \\
& 578 & 5344 & 84 \\
& 736 & 3869 & 104 \\
& 575 & 4906 & 80 \\
& 539 & 5153 & 81 \\
& $\mathbf{6 4 7} \pm \mathbf{1 1 8}$ & $\mathbf{4 7 9 6} \pm \mathbf{5 7 2}$ & $\mathbf{9 2} \pm \mathbf{1 5}$ \\
\hline
\end{tabular}

Values from five parallel samples are shown together with the averages (in bold font).

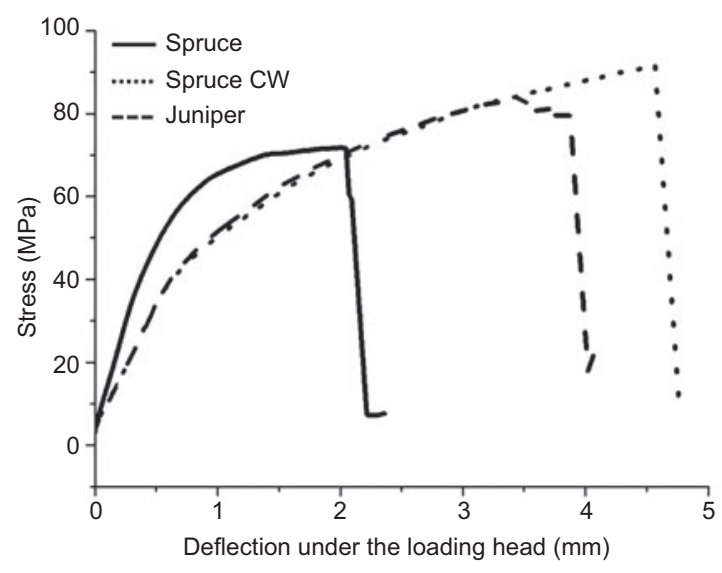

Figure 5 Stress versus deflection under the loading head curves of juniper, spruce, and spruce compression wood.

Spruce CW and juniper both display slightly higher bending strengths than the spruce NW. When density is taken into account, the specific strength of all groups is comparable. Generally, MFA has a strong effect on the tensile strength, with higher MFAs leading to lower tensile strength (Page et al. 1972). By contrast, compression strength rises almost linearly with density in air-dried wood. In bending, both tensile and compressive stresses are present and thus it may be presumed that the competing effects cancel each other. Nevertheless, differences in the fracture behavior were observed. As expected, in all juniper and spruce CW specimens failure began on the side under tension, whereas in the NW of spruce both tension and compression failures occurred.

Typical stress-deflection histories are presented in Figure 5. As is visible, the deflection of juniper and spruce CW at failure is much larger than that of the spruce NW. By comparing the areas under the stress-deflection curves it is obvious that juniper and spruce $\mathrm{CW}$ are able to dissipate significantly greater amounts of energy prior to fracture.

The Klason lignin content of spruce NW is significantly lower than in CW, as expected (Timell 1986; Yeh et al. 2006). The lignin content of juniper is higher than that of spruce but it is lower than in CW and corresponds well with the lignin content of juniper reported earlier (Timell 1986). The samples with higher lignin content also possess higher density. Juniper and spruce $\mathrm{CW}$ containing high lignin contents are significantly denser than spruce NW. The extractives content of juniper is significantly greater than that of spruce NW and spruce $\mathrm{CW}$, whereas the latter has slightly elevated extractives content compared to spruce NW (Table 3).

Table 3 Lignin and extractives contents (\% of wood) of spruce, spruce compression wood and juniper.

\begin{tabular}{lccc}
\hline & \multicolumn{2}{c}{ Lignin (\%) } & \\
\cline { 2 - 3 } \multicolumn{1}{c}{ Sample } & Acid soluble & Klason & Extractives (\%) \\
\hline Spruce & 0.5 & 28.9 & 0.9 \\
Spruce CW & 0.5 & 36.6 & 1.7 \\
Juniper & 0.7 & 30.1 & 5.8 \\
\hline
\end{tabular}


Table 4 Carbohydrate composition (\%) in acid hydrolysates of spruce, spruce compression wood $(\mathrm{CW})$, and juniper.

\begin{tabular}{lccc}
\hline & \multicolumn{3}{c}{ Spruce } \\
\cline { 2 - 3 } Sugar & NW (\%) & CW (\%) & Juniper (\%) \\
\hline Ara & 1.3 & 1.1 & 1.4 \\
Rha & 0.3 & 0.4 & 0.5 \\
Gal & 5.5 & 17.5 & 7.4 \\
Glc & 67.7 & 59.5 & 61.9 \\
Xyl & 9.0 & 10.4 & 11.9 \\
Man & 16.3 & 11.2 & 17.1 \\
\hline
\end{tabular}

Ara, arabinose; Rha, rhamnose; Gal, galactose; Glc, glucose; Xyl, xylose; Man, mannose.

The spruce CW and juniper contain higher amounts of non-cellulosic carbohydrates than the spruce NW (Table 4). This is a known characteristic difference between NW and CW (Timell 1986). Spruce CW contains a large amount of galactose originating from (1-4)- $\beta$-galactan which is reportedly higher in CW (Yeh et al. 2006; Mast et al. 2009). This type of polysaccharide is situated mainly in the $S 2_{(\mathrm{L})}$ layer in particular (Altaner et al. 2007, 2010). Slightly elevated xylose contents were also observed in juniper and spruce CW.

Raman images (Figure 6) show an even lignin/cellulose distribution in juniper, whereas the lignin content increases drastically in the primary cell wall (S1) and in the composed middle lamella (CML). A similar distribution was observed for Juniper excelsa (Adamopoulos and Koch 2011) by UMSP, although the resolution of this instrument is not high enough to distinguish clearly between small details in the cell wall. Raman images illustrating the lignin and lignin/cellulose distributions in the cell walls (Figure 6) resemble previously published ones (Gierlinger et al. 2010). The lignin/cellulose distribution of juniper is similar to that of spruce $\mathrm{NW}$, whereas the additional lignin layer $\mathrm{S} 2_{(\mathrm{L})}$ can only be observed in the $\mathrm{CW}$ samples. No differences in distribution could be detected between the images taken from different growth rings in any of the samples.
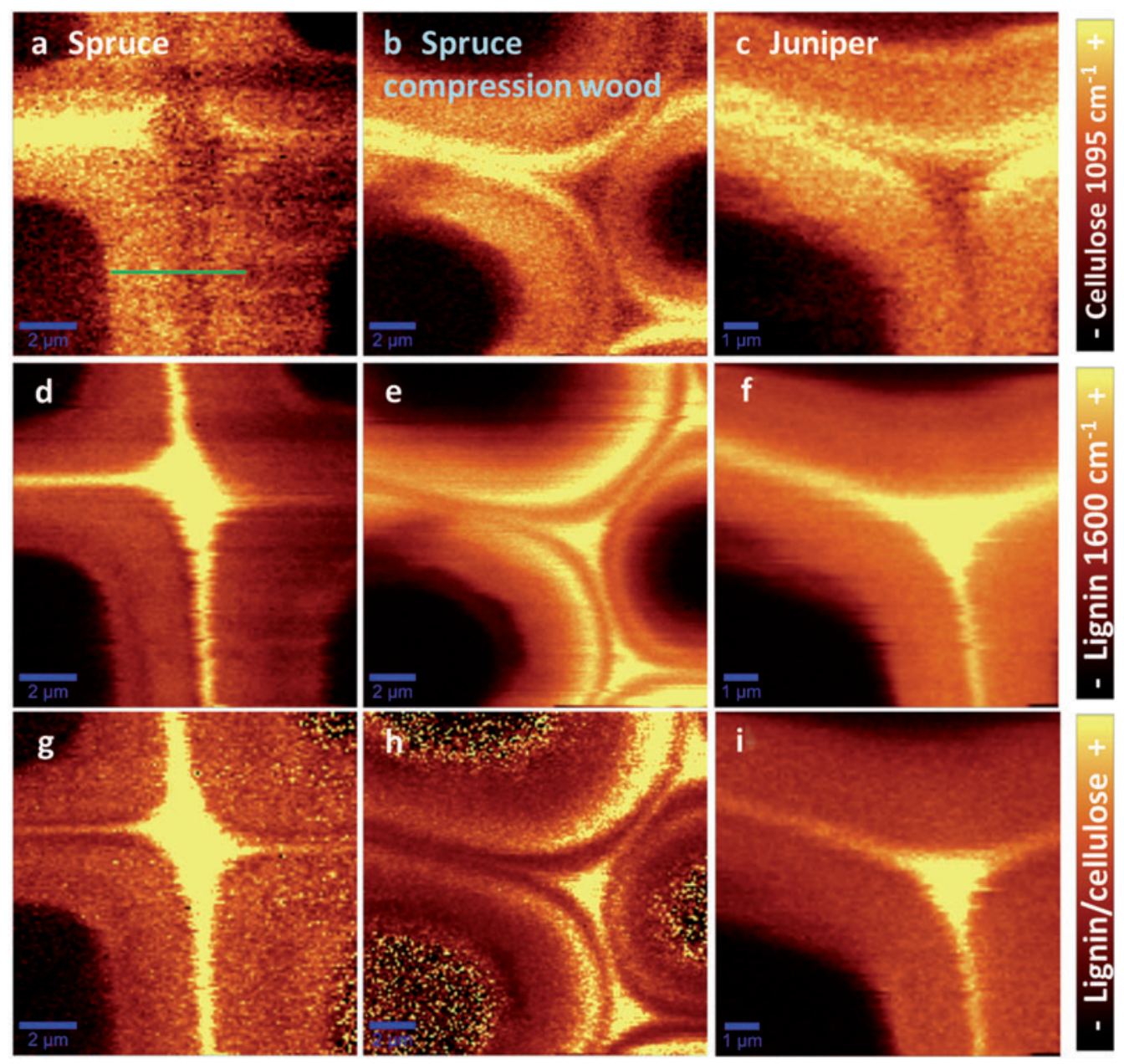

Figure 6 Raman images of spruce, spruce compression wood, and juniper. Images are constructed according to area of characteristic Raman bands of cellulose $(a-c)$, lignin $(d-f)$, and lignin/cellulose ratio $(g-i)$. Laser polarization direction is indicated with green line. Scale in lignin/ cellulose ratio images of spruce and juniper ( $g$ and i) images ranges from 0 to 6 arbitrary units and for spruce compression wood (h) from 0 to 12 arbitrary units. 
Measurements by polarized laser in Raman spectroscopy enable the detection of S1 cell wall because the Raman spectrum of cellulose is sensitive to orientation (Atalla et al. 1980; Wiley and Atalla 1987; Gierlinger et al. 2010). The S1 layer is aligned along the plane of polarization of the laser (horizontal cell walls layer) and appears bright in the Raman images based on the characteristic cellulose band at $1095 \mathrm{~cm}^{-1}$ (Figure $6 \mathrm{a}-\mathrm{c}$ ). The bright color indicating larger area for this Raman band is a feature arising from the orientation of cellulose in the S1 layer. Therefore, the intensity of Raman scattering does not correlate with the concentration of cellulose in this case. This feature, however, is useful for distinguishing the S1 layer from the S2. No noticeable difference could be observed in the thickness of the S1 layers, which differs from the MFA determination by XRD. In XRD data, contribution of another cell wall layer with very low MFA could be distinguished, which is probably due to thick S1 layers. The poor resolution of Raman imaging and the fact that only LW cells were analyzed may explain the finding that $\mathrm{S} 1$ thicknesses could not be differentiated.

\section{Conclusions}

Literature data about $J$. communis could be confirmed and specified concerning its CW-like features, such as helical grooves, fiber dimensions (Hänninen et al. 2011a), high elasticity, and high MFA. The helical grooves of a typical CW correlated with the MFA, which was ca. $35^{\circ}$ in juniper and spruce CW. Also, the crystal length of cellulose in the cell walls of juniper is very similar to that of CW spruce. By contrast, it resembles to NW of almost any other wood species concerning the carbohydrate composition and especially the distribution of lignin and cellulose (Agarwal 2006; Gierlinger and Schwanninger 2006; Schmidt et al. 2009; Gierlinger et al. 2010; Hänninen et al. 2011b). The small amount of galactose, that is usually abundant in CW as (1-4)- $\beta$-galactan, indicated that juniper is closer to NW in its carbohydrate composition. As the wood densities of juniper and spruce $\mathrm{CW}$ are higher than the density of NW spruce, it can be concluded that the low MOE of juniper is due to high MFA.

The similarities and dissimilarities of juniper wood with CW can partly explain several of its peculiar material properties. Elucidation of the enzymatic mechanisms or genetics of the partly CW-like character of juniper could help understand the formation of reaction wood, in general, and the peculiarities of this interesting wood.

\section{Acknowledgments}

This work was part of projects supported by the Multidisciplinary Institute of Digitalization and Energy (MIDE, http://mide.tkk.fi). The work was also supported by the Academy of Finland (1127759).

\section{References}

Adamopoulos, S., Koch, G. (2011) Wood structure and topochemistry of Juniperus excelsa. IAWA J. 32:67-76.
Agarwal, U.P. (2006) Raman imaging to investigate ultrastructure and composition of plant cell walls: distribution of lignin and cellulose in black spruce wood Picea mariana. Planta 224:1141-1153.

Altaner, C., Hapca, A., Knox, J.P., Jarvix, M. (2007) Detection of $\beta$-1-4-galactan in compression wood of Sitka spruce [Picea sitchensis (Bong.) Carrière] by immunofluorescence. Holzforschung 61:311-316.

Altaner, C.M., Tokareva, E.N., Jarvis, M.C., Harris, P.J. (2010) Distribution of $(1 \rightarrow 4)-\beta$-galactans, arabinogalactan proteins, xylans and $(1 \rightarrow 3)-\beta$-glucans in tracheid cell walls of softwoods. Tree Physiol. 30:782-793.

Andersson, S., Serimaa, R., Pakkkari, T., Saranpää, P., Pesonen, E. (2003) Crystallinity of wood and the size of cellulose crystallites in Norway spruce (Picea abies). J. Wood Sci. 49:531-537.

Atalla, R.H., Whitmore, R.E., Heimbach, C.J. (1980) Raman spectral evidence for molecular orientation in native cellulosic fibers. Macromolecules 13:1717-1719.

Brändström, J. (2001) Micro- and ultrastructural aspects of Norway spruce tracheids: a review. IAWA J. 22:333-353.

Burgert, I., Frühmann, K., Keckes, J., Fratzl, P., Stanzl-Tschegg, S. (2004) Structure-function relationships of four compression wood types: micromechanical properties at the tissue and fibre level. Trees Struct. Funct. 18:480-485.

Davidson, T.C., Newman, R.H., Ryan, M.J. (2004) Variations in the fibre repeat between samples of cellulose I from different sources. Carbohydr. Res. 339:2889-2893.

Donaldson, L.A., Singh, A.P., Yoshinaga, A., Takabe, K. (1999) Lignin distribution in mild compression wood of Pinus radiata. Can. J. Bot. 77:41-50.

Eckenwalder, J.E. (2009) Conifers of the World. Timber Pree Inc., London, IK.

Evans, R., Ilic, J. (2001) Rapid prediction of wood stiffness from microfibril angle and density. For. Prod. J. 51:53-57.

Gere, J.M. (1997) Mechanics of Materials. PWS Publishing, Boston.

Gierlinger, N., Luss, S., König, C., Konnerth, J., Eder, M., Fratzl, P. (2010) Cellulose microfibril orientation of Picea abies and its variability at the micron-level determined by Raman imaging. J. Exp. Bot. 61:587-595.

Gierlinger, N., Schwanninger, M. (2006) Chemical imaging of poplar wood cell walls by confocal Raman microscopy. Plant Physiol. 140:1246-1254.

Gindl, W. (2002) Comparing mechanical properties of normal and compression wood in Norway spruce: the role of lignin in compression parallel to the grain. Holzforschung 56:395-401.

Gindl, W., Teischinger, A.A. (2003) Comparison of the TL-shear strength of normal and compression wood of European larch. Holzforschung 57:421-426.

Hänninen, T., Kontturi, E., Leppänen, K., Serimaa, R., Vuorinen, T. (2011a) Kraft pulping of Juniperus communis results in paper with unusually high elasticity. Bioresources 6: 3824-3835.

Hänninen, T., Kontturi, E., Vuorinen, T. (2011b) Distribution of lignin and its coniferyl alcohol and coniferyl aldehyde groups in Picea abies and Pinus sylvestris as observed by Raman imaging. Phytochemistry 72:1889-1895.

Kantola, M., Kähkönen, M. (1963) Small-angle X-ray investigation of the orientation of crystallites in Finnish coniferous and deciduous wood fibers. Ann. Acad. Sci. Fenn. A VI 137:3-14.

Kantola, M., Seitsonen, S. (1961) X-Ray orientation investigations on Finnish conifers. Ann. Acad. Sci. Fenn. A VI 80:3-15.

Keunecke, D., Eder, M., Burgert, I., Niemz, P. (2008) Micromechanical properties of common yew (Taxus baccata) and Norway spruce 
(Picea abies) transition wood fibers subjected to longitudinal tension. J. Wood. Sci. 54:420-422.

Kibblewhite, R.P., Suckling, I.D., Evans, R., Grace, J.C., Riddell, M.J.C. (2010) Lignin and carbohydrate variation with earlywood, latewood, and compression wood content of bent and straight ramets of a radiata pine clone. Holzforschung 64:101-109.

Leppänen, K., Andersson, S., Torkkeli, M., Knaapila, M., Kotelnikova, N., Serimaa, R. (2009) Structure of cellulose and microcrystalline cellulose from various wood species, cotton and flax studied by X-ray scattering. Cellulose 16:999-1015.

Mast, S.W., Donaldson, L., Torr, K., Phillips, L., Flint, H., West, M., Strabala, T.J., Wagner, A. (2009) Exploring the ultrastructural localization and biosynthesis of $\beta(1,4)$-galactan in Pinus radiata compression wood. Plant Physiol. 150:573-583.

McLean, J.P., Evans, R., Moore, J.R. (2010) Predicting the longitudinal modulus of elasticity of Sitka spruce from cellulose orientation and abundance. Holzforschung 64:495-500.

Nanayakkara, B., Manley-Harris, M., Suckling, I.D., Donaldson, L.A. (2009) Quantitative chemical indicators to assess the gradation of compression wood. Holzforschung 63:431-439.

Önnerud, H. (2003) Lignin structures in normal and compression wood. Evaluation by thioacidolysis using ethanethiol and methanethiol. Holzforschung 57:377-384.

Page, D.H. (1983) The origin of the differences between sulphite and kraft pulps. J. Pulp. Pap. Sci. 9:TR15-TR20.

Page, D.H., El-Hosseiny, F., Winkler, K., Bain, R. (1972) The mechanical properties of single wood-pulp fibres. Part I: a new approach. Pulp Pap. Can. 73:72-77.

Perré, P. (2007) Experimental device for the accurate determination of wood-water relations on micro-samples. Holzforschung 61:419-429.

Placet, V., Passard, J., Perré, P. (2007) Viscoelastic properties of green wood across the grain measured by harmonic tests in the range $0-95^{\circ} \mathrm{C}$ : hardwood vs. softwood and normal wood vs. reaction wood. Holzforschung 61:548-557.

Salmén, L., Burgert, I. (2009) Cell wall features with regard to mechanical performance. A review. Holzforschung 63:121-129.

Schmidt, M., Schwartzberg, A., Perera, P., Weber-Bargioni, A., Carroll, A., Sarkar, P., Bosneaga, E., Urban, J., Song, J.,
Balakshin, M., Capanema, E., Auer, M., Adams, P., Chiang, V., Schuck, P. (2009) Label-free in situ imaging of lignification in the cell wall of low lignin transgenic Populus trichocarpa. Planta 230:589-597.

Sluiter, A., Hames, B., Ruiz, R., Scarlata, C., Sluiter, B., Templeton, D., Crocker, D. (2008) Determination of structural carbohydrates and lignin in biomass. NREL Laboratory Analytical Procedure (LAP). National Renewable Energy Laboratory, http://www.nrel. gov/biomass/analytical_procedures.html.

Tanaka, F., Koshijima, T., Okamura, K. (1981) Characterization of cellulose in compression and opposite woods of a Pinus densiflora tree grown under the influence of strong wind. Wood Sci. Technol. 15:265-273.

Tarmian, A., Perré, P. (2009) Air permeability in longitudinal and radial directions of compression wood of Picea abies L. and tension wood of Fagus sylvatica L. Holzforschung 63: 352-356.

Timell, T.E. (1982) Recent progress in the chemistry and topochemistry of compression wood. Wood Sci. Technol. 16:83-122.

Timell, T.E. (1983) Origin and evolution of compression wood. Holzforschung 37:1-10.

Timell, T.E. (1986) Compression Wood in Gymnosperms. Vol. 1. Springer-Verlag, Berlin.

Tokareva, E.N., Pranovich, A.V., Fardim, P., Daniel, G., Holmbom, B. (2007) Analysis of wood tissues by time-of-flight secondary ion mass spectrometry. Holzforschung 61:647-655.

Yeh, T.-F., Goldfarb, B., Chang, H.-M., Peszlen, I., Braun, J.L., Kadla, J.F. (2005) Comparison of morphological and chemical properties between juvenile wood and compression wood of loblolly pine. Holzforschung 59:669-674.

Yeh, T.-F., Braun, J.L., Goldfarb, B., Chang, H.-M., Kadla, J.F. (2006) Morphological and chemical variations between juvenile wood, mature wood, and compression wood of loblolly pine (Pinus taeda L.) Holzforschung 60:1-8.

Wiley, J.H., Atalla, R.H. (1987) Band assignments in the raman spectra of celluloses. Carbohydr. Res. 160:113-129.

Received May 26, 2011. Accepted October 10, 2011.

Previously published online November 16, 2011. 